\title{
Research activities in the Gulf of Lion (NW Mediterranean) within the 1997-2001 PNEC project
}

\section{Bilan des activités du Chantier «golfe du Lion » du PNEC durant la période 1997-2001}

\author{
Patrick Raimbault ${ }^{\mathrm{a}, *}$, Xavier Durrieu de Madron ${ }^{\mathrm{b}}$ \\ ${ }^{a}$ Laboratoire d'océanographie de biogéochimie, CNRS, University of Aix-Marseille II, Campus de Luminy, 13288 Marseille cedex 9, France \\ ${ }^{b}$ CEFREM, CNRS, Université de Perpignan, 52, avenue de Villeneuve, 66860 Perpignan cedex, France
}

\begin{abstract}
The French national program on the coastal environment Programme National Environnement Côtier (PNEC) represented during the last decade a major support for the pluridisciplinary oceanographic research in the Gulf of Lion. During the second phase of the program, that lasted from 1997 to 2001, the main objective for this worksite was to establish an annual budget of carbon and associated biogenic elements to characterise the role of this region as source and the sink of elements. This introductory paper provides an overview of the research framework and recapitulates the major scientific outcomes.
\end{abstract}

(C) 2003 Éditions scientifiques et médicales Elsevier SAS and Ifremer/CNRS/IRD. All rights reserved.

\section{Résumé}

The Programme National Environnement Côtier (PNEC) a fourni, durant la dernière décennie, un soutien important pour la recherche océanographique pluridisciplinaire sur le golfe du Lion. L'objectif principal de la seconde phase du programme, entre 1997 et 2001 , était de construire un bilan annuel de carbone et d'éléments biogéniques associés afin de caractériser le rôle de cette région comme source ou puits de matière. Cet article introductif présente une vue d'ensemble du cadre de recherche et récapitules les résultats scientifiques majeurs.

(C) 2003 Éditions scientifiques et médicales Elsevier SAS and Ifremer/CNRS/IRD. All rights reserved.

Keywords: Coastal environment; Gulf of Lion; Pluridisciplinary; Budget

Mots clés : Environment côtier ; Golfe du Lion ; Pluridisciplinaire ; Bilan

\section{Introduction}

\subsection{The Gulf of Lion worksite}

The Gulf of Lion in the northwestern Mediterranean Sea is, since its creation in the early 1990s, one of the worksite of the French national program on the coastal environment Programme National Environnement Côtier (PNEC). This region offers several factors of interest: it represents a welldefined continental shelf that receives considerable inputs

* Corresponding author.

E-mail address: patrick.raimbaul@ com.univ-mrs.fr (P. Raimbault). from the Rhone river and is one of the most productive regions of the Mediterranean. Mesoscale features large shelf-slope exchanges and specific wind-driven processes (upwelling, downwelling, and dense water formation) dominate the water circulation. Hence, the Gulf of Lion is a favourable site to investigate the interactions between the spatial and temporal variability of water circulation, the inputs of riverine nutrients and biological activity. It provides a complex example of the carbon cycle in a coastal environment Fig. 1. This introductory paper aims at setting the framework of the research project for the Gulf of Lion and at recapitulating the major scientific outcomes that are presented in the following papers as well as previously published papers. 




Fig. 1. Location of the Gulf of Lion and major hydrological regions on the continental shelf.

\subsection{Objectives for the 1997-2001 period}

During the second phase of the program, that lasted from 1997 to 2001, the main objective for this worksite was to establish an annual budget of carbon and associated biogenic elements to characterise, in particular, the role of this region as source and the sink of elements. The different facets of this study concerned (i) the quantification of the riverine discharges, (ii) the dispersal of the freshwater plume and the short-term impact of riverborne nutrients on the pelagic production, (iii) the seasonality of the distribution on the whole shelf of nutrients and primary production with respect to the mesoscale dynamics of the water masses, as well as the variability of benthic response and nutrients fluxes at the water-sediment interface, (iv) the exchanges of matter between the shelf and the slope and (v) the effect of climatic hazards (e.g. large southeastern storm) on the benthic and pelagic ecosystem.

The complexity and interdisciplinary nature of the project required a substantial coordinated effort, and diverse scientific expertise. Height laboratories and 48 scientists participated to the project. Eighty cruises, totalling about $450 \mathrm{~d}$ at sea, were carried out. The budget allocated for the 19972001 period amounted to $€ 375000$. The program was back up by the French national program on atmospheric and oceanic research at mesoscale Patom (Programme Atmosphère et Océan à Moyenne Echelle) and three European projects: Metro-Med (dynamics of matter transfer and biogeochemical cycles: their modelling in coastal systems of the Mediterranean Sea), Mater (mass transfer and ecosystems response) and MFSPP (Mediterranean forecasting system pilot project), that addressed specific points such as the modelling of the water circulation and the characterisation of shelfslope exchange processes. All the data collected are now included in database that will be in free access in 2003 (http://www.com.univ-mrs.fr/). The locations corresponding to the different field works conducted between 1997-2000 and 2000-2001 are presented in Fig. 2a,b respectively.
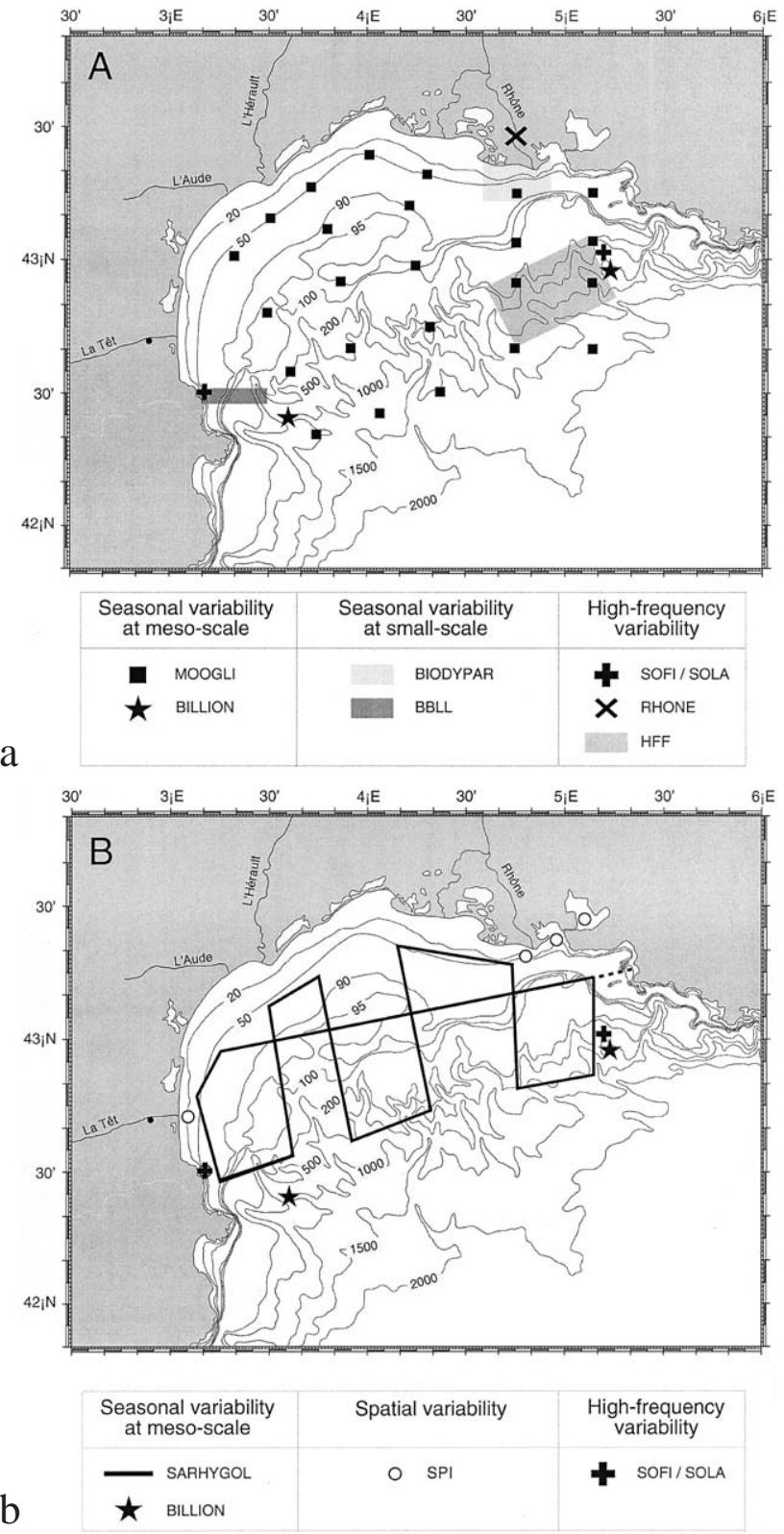

Fig. 2. Map of the Gulf of Lion showing locations of main investigated sites: (a) during the 1997-1999 period and (b) during the 2000-2001 period.

\section{Main results}

\subsection{The Rhone river and the plume}

\subsubsection{Nutrients inputs}

From the work carried out over the last 20 years, it has been first concluded that the mean annual nitrate concentration in the Rhone increased by $50 \%$ during the last decade (Moutin et al., 1998). However, data collected between 1997 and 2000 lead to the conclusion that nitrate concentration started to decrease since 1997. We estimated the annual input of nitrogen and phosphorus to 123 and $8 \mathrm{kt}$, respectively. Whereas most of the nitrogen inputs (68\%) are inorganic nitrogen (nitrate) immediately used by phytoplankton, a large part of the phosphorus (52\%) is in organic forms not 
immediately available for primary producers. Moreover, $25 \%$ of the phosphorus inputs are in forms of particulate matter that rapidly sinks near the Rhone river mouth.

\subsubsection{Freshwater plume dynamics}

Broche et al. (1998) studied the dynamic and hydrological field on the basis of Eulerian VHF radar mapping of surface current coupled with Lagrangian in situ physical and geochemical measurements. They show that the plume morphology (i.e. orientation and offshore extension) is controlled by the wind and outflow forcing conditions, and that vertical structure changes from an almost unaltered twolayer distribution, to an evolving and deepening mixed layer, or even to a more complex superimposed multi-layered structure.

The modelling work of Estournel et al. (2001) successfully reproduces the main characteristics of the Rhone river plume subject to varying wind. In the case of a constant wind blowing from the Northwest, the plume is pushed to the open sea, and therefore, does not playa major role in enriching the coastal zone of the Gulf of Lion. On the contrary, changes in the wind lead to larger dispersion and longer residence times on the shelf, leading to more enrichment of the coastal zone in riverborne elements.

The numerical modelling work by Arnoux-Chiavassa et al. 2003, presented in this volume, addresses the effects of discretization scheme on the description of 3D Rhone river plume dynamics. For the case without wind stress, associated to supercritical values of the Richardson number, optimised turbulent parameterisation allows to recover the plume spreading and thickness, although local diffusion mechanisms are not precisely described. For the seaward wind case, associated to subcritical values of the Richardson number, numerical results and in situ data well agree on both the surface flow and the vertical density structure.

\subsubsection{Dispersal of particulate and dissolved matter}

Thill et al. (2001) combined field studies and laboratory experiments to assess the importance of salt induced flocculation in the case of the salt-wedge estuary of the Rhone river. Sampling of the mixing zone was performed in contrasted hydrodynamic conditions from a low water discharge period to a small flood event. They argued that the particulate matter has a poor average reactivity regarding salt induced flocculation and that the evolution of the concentration of larger particles $(>5 \mu \mathrm{m})$ can be explained by settling and dilution. In contrast, the smallest measured fraction $(2-5 \mu \mathrm{m})$ shows a more complex behaviour and it is suggested that colloid aggregation could participate to their formation.

Concerning remote-sensed observations of the turbid plume, Forget et al. $(1999,2001)$ studied the sensitivity of spectral reflectance to variations of solid suspended matter concentration with depth. They developed an inversion method for the radiative transfer model restricted to the simple case of a two-layer ocean and tested it on various documented experimental data. Reasonably good estimates of the mean sediment concentration of the upper layer were obtained, but only the order of magnitude of the mean concentration of the lower layer was recovered.

The 1996-2000 Sorcom time series, consisting of a biweekly hydrological transect between Marseilles and the Rhone river's mouth, aimed at characterising spatial extension and temporal evolutions of the freshwater plume (Younes et al., this issue). The Gulf of Marseilles, which is seldom influenced by the Rhone freshwater, showed classical marine water seasonality, but with earlier phytoplanktonic bloom than usually reported. The region of freshwater influence showed a weaker seasonal variability of the phytoplanktonic biomass.

Naudin et al. (2001) focussed on biological processes involved during mixing of a river plume with the marine underlying water, using a Lagrangian sampling strategy. They show that temperature, light conditions and suspended matter play a minor role upon biological activity by comparison with freshwater plume's dilution and nutrient availability. In windless conditions and close to the river mouth, the density gradient between marine and river water induced limited exchanges between the nutrient-rich freshwater and the potential consumers in the underlying marine water. Offshore, mixing is enhanced and a balance is reached between salinity tolerance and nutrient availability to form a favourable zone for marine phytoplankton development. Under windy and wavy conditions, the rapid mixing of the plume reduced the extension of the "enhanced production zone" and even inhibits the bacterial activity.

\subsection{Circulation and distribution of elements at mesoscale}

\subsubsection{Water mass circulation}

The water mass circulation on the continental shelf and its spatial and temporal variability were not very well known. Acoustic Doppler current profilers (ADCPs), now hullmounted on some of the research vessels, provide data to fill this gap. Three seasonal surveys performed by the R/V Le Surôtt, during the Moogli cruises (Fig. 2b), provide quasisynoptic pictures of the surface layer circulation. Besides, current meter moorings and hydrological surveys on the continental slope (Billion and HFF arrays) provided a complementary description of the intermediate layer circulation. These data, complemented with sea surface temperature images, allow to determine the origin and seasonality of the major hydrodynamic features.

During Moogli cruises the Mediterranean Northern Current (NC), with a transport of $\sim 2 \mathrm{~Sv}\left(2 \times 10^{6} \mathrm{~m}^{3} \mathrm{~s}^{-1}\right)$, is clearly detected along the continental slope and intrudes on the eastern side of the shelf. During summer, the NC is wider, shallower and slower than during winter (Petrenko, this issue; Lapouyade and Durrieu de Madron, 2001). The meanders of the NC are interpreted as due to baroclinic instabilities propagating along the shelfbreak (Flexas et al., 2002). 
The paper by Estournel et al., 2003 deals with the observation and modelling of the effect of the wind forcing on the oceanic circulation and the hydrological structures. It reveals that the mesoscale structure of the wind field, constrained by the local orography, controls the generation of oceanic eddies on the shelf and the exchanges of water between the shelf and the slope.

Other circulation features are season-specific. Petrenko (this issue) shows that the summer stratification leads to the development, after strong wind variations, of strong and coherent inertial currents with their characteristic two-layer baroclinic structure. During winter 1999, dense water formations, due to strong wind-induced cooling, are observed both on the continental shelf and offshore. An intense cascading of dense shelf water, detected in February 1999 on the lower slope, is believed to be at the origin of the new deep water anomaly observed throughout the western Mediterranean basin during spring and summer 1999 (Béthoux et al., 2002).

\subsubsection{Numerical modelling of oceanic circulation}

Echevin et al., 2003a demonstrates the feasibility of a downscaling system composed of a general circulation and a regional model within the framework of the MFSPP. The regional model reproduces several realistic features of the large scale and mesoscale circulations (i.e. mean cyclonic circulation, mesoscale variability and meanders of the NC, formation of Winter Intermediate Water).

Echevin et al., 2003b studied the interaction of a coastal current with a shallow shelf and its application to the Gulf of Lion. An analytical analysis of the wave propagation along a step-like bottom topography in a two-layer fluid reveals the propagation of two different waves along the shelfbreak. More realistic configurations (idealised shallow gulf and realistic topography) were explored using a primitiveequation model. It is shown that the steady current component of the coastal current follows the shelfbreak, and that a transient cross-shelf transport can be induced by the current fluctuations.

Verdier-Bonnet et al. (1999) studied the relevance of the isotropic eddy viscosity assumption of the standard $k-\epsilon$ model for stratified and shallow-water flows submitted to the Coriolis force with two corrected $k-\epsilon$ models. They focus onto two main sources of turbulent oceanic energy: the surface current shear induced by wind and the bottom stress due to tidal circulation. The $k-\epsilon$ closure model corrected to account for non-isotropic effects is used to model idealised wind-driven stratified coastal flows such as coastal upwelling.

The 3D hydrodynamic coastal model, symphonie, developed at Laboratoire d'Aérologie from Toulouse has been used as a tool to analyse the data collected during the Moogli cruises. Inverse modelling based on the linearised equations of the coastal model enabled to reduce the unrealistic spin up of a free surface model resulting from unbalanced dynamical initial fields under bottom slope influence (Auclair et al., 2000a). This inverse method was successfully extended to the reduction of the truncation errors characterising sigma coordinate model over steep bathymetry (Auclair et al., 2000b). Practically, inverse modelling has been used to provide an initial state and time variations of the open boundary conditions to a high resolution free surface sigma coordinate model, using weekly averaged fields of a large scale rigid lid $z$-coordinate model of the Mediterranean sea. The interaction of the slope current with the shelf circulation of the Gulf of Lion was then investigated (Auclair et al., 2001). Sensitivity of the Gulf of Lion circulation to various forcing, wind stress, fresh water discharge, 3D hydrologic structures and inflow characteristics of the NC were recently studied thanks to an "ensemble simulation" method (Auclair et al., 2003).

Estournel et al., 2003 showed for the Moogli 1 cruise (April-May 1998) that the mesoscale wind curl linked to the channelling effect of the Rhone valley for the Mistral and of the Naurouze passage for the Tramontane is the driving force for the shelf circulation. The export of water out of the Gulf by the complex wind driven coastal currents is compensated by offshore water intrusions onto the shelf achieved through cross-slope currents. An important conclusion of this study is that the wind field at a high spatial and temporal resolution is a crucial parameter for the quantification of the exchanges between the coast and the open ocean. A simulation for the Moogli 3 cruise (winter 1998-1999) reproduced the observed meanders of the NC along the slope. It further indicates that the dense water flow observed by Béthoux et al. (2002) in the western part of the gulf originate from the Roussillon's coast, large heat losses associated to persistent strong winds and cold weather were recorded.

\subsection{Pelagic production and vertical fluxes}

\subsubsection{Seasonal variation}

Diaz (2000) measured primary production, using the ${ }^{14} \mathrm{C}$ tracer coupled with nitrogen uptake experiments using ${ }^{15} \mathrm{~N}$ tracer, on a monthly basis at the SOFI site and on the whole gulf at three seasons during Moogli cruises. Annual budgets of primary production and new production are estimated to $71 \pm 7$ and $37 \pm 4 \mathrm{~g} \mathrm{C} \mathrm{m}^{-2}$, respectively. Furthermore, measurements of dissolved organic matter and particulate organic matter (POM) reveal a net accumulation of dissolved organic carbon (DOC) during summer. DOC accumulation represents more than $55 \%$ of primary production, values higher than those observed in other parts of the Mediterranean Sea $(6-23 \%)$. This DOC accumulation is certainly strongly marked by the permanent Rhone input and can be explained by the phosphorus limitation, which leads to an incomplete DOC utilisation by bacteria. Diaz et al. (2000) emphasised the importance during spring of short-term changes in water masses around the shelfbreak on biological productivity. They show that the production regimes changed within a few weeks because of intrusions of nitrate-rich 
coastal water and intermediate slope water. Van Wambeke et al. (2002) similarly concluded, through a comparison of primary production with measured and estimated organic carbon removal terms (sinking, cycling through the microbial food web, grazing by ciliates and metazoans), that lateral advection of carbon and accumulation of DOC play a significant role in the carbon cycle at the shelfbreak.

In the latter context of the spring short-term variability in water masses, a fine depiction of nitrogen fluxes as the heterotrophic ammonium regeneration, the bacterial nitrification and the losses of dissolved organic nitrogen by phytoplankton assemblages that have been rarely measured in the Gulf of Lion worksite was given in Diaz and Raimbault (2000). They emphasise the implications of these latter nitrogen fluxes for the estimation of the spring new production.

Gaudy et al., this issue study the biomass, nutrition and metabolisms of zooplankton during the three Moogli cruises, and conclude that nitrogen and phosphorus excreted by zooplankton accounted for 31 and $10 \%$ of the primary production requirements in spring and for 32 and $>100 \%$ in winter. Grazing impact ranged between 9 and 69\% of the primary production in spring and $6-83 \%$ in winter. The average secondary production was $54 \mathrm{mg} \mathrm{C} \mathrm{m}^{-2} \mathrm{~d}^{-1}$ in spring and 19 $\mathrm{mg} \mathrm{m}^{-2} \mathrm{~d}^{-1}$ in winter, which represents 11 and $12 \%$ of the primary production, respectively.

\subsubsection{Phosphorus limitation}

Diaz et al. (2001) show from the distribution of dissolved inorganic nitrogen and phosphorus distributions a clear phosphorus-deficiency in the Gulf of Lion. Below $150 \mathrm{~m}$ depth, nitrate/phosphate ratios are close to the typical Mediterranean ratio of 21 , but values observed in surface waters are much higher (up to 100). This imbalance appears immediately at the end of winter when phosphate concentrations become undetectable, while nitrate concentrations remain to significant values $\left(2 \mu \mathrm{mol} \mathrm{l}^{-1}\right)$. P-deficiency limits the nitrate utilisation by phytoplankton and is the main factor controlling primary production.

\subsubsection{Silicon seasonal cycle}

Leblanc et al., this issue conducted a study of the biogeochemical cycle of silicon ( $\mathrm{Si}$ ) at the SOFI site from September 1999 to September 2000. They show a clear seasonal cycle of biogenic silica (BSi) and lithogenic silica (LSi) standing stocks. Integrated biogenic silica was highest in spring and summer during the major phytoplankton developments. In winter relatively high $\mathrm{Chl} a$ concentrations originating from non-siliceous phytoplankton were sustained over the water column. Due to frequent wind events the water column was well mixed during winter, allowing sediment resuspension and resulting in high LSi integrated stocks. The observed cycle is similar to that observed in other oligotrophic open-ocean systems in terms of stocks, annual Si production rates, and the relative contribution of diatoms to phytoplanktonic primary production.

\subsubsection{Numerical modelling of the pelagic trophic food} web

A biogeochemical model composed with seven variables in terms of nitrogen and four in terms of phosphorus is coupled with the hydrodynamical model (Diaz, 2000). Biogeochemical processes that are taken into account are new production, regenerated production, recycling processes (nitrification, dissolved organic nitrogen, ammonium and phosphate regeneration), grazing by zooplankton, phytoplankton aggregation and predation by zooplankton. Special characteristic of Mediterranean nutrient fields (i.e. dissolved inorganic phosphorus deficiency regarding dissolved inorganic nitrogen) is considered by including an explicit limitation of new production by phosphorus. The first study focuses on the validation of the biogeochemical model from the Moogli 1 cruise performed during the 1998 spring bloom. Results of model were compared to field results obtained during the second set of sampling 3 weeks later. The first results of this model concern the annual budget of carbon and the fate of the production. The Gulf of Lion appears as a privileged region for production and export. Biomass fluxes are more important in the west than in the east in relation with meteorological conditions, especially wind forcing.

Tusseau-Vuillemin et al. (1998) estimated nitrogen fluxes in the Gulf of Lion during an annual cycle from a biogeochemical model coupled with a general circulation model. The simulation of chlorophyll $a$, nutrient concentrations and primary production is quite satisfactory compared with coastal zone colour scanner images and other data collected in the gulf. Model results indicate that, regarding the open sea, the margin acts most of the time as a sink for nitrate. However, during winter, when phytoplankton growth is reduced and cascading of dense waters is active along the shelf, the margin is shown to export nitrate towards the open sea.

\subsection{Benthic response and exchanges at the water-sediment interface}

\subsubsection{Biochemical characteristics of sedimented particulate organic matter}

Grémare et al., 2003a, 2003b aim at identifying biochemical descriptors of sedimented POM nutritive value to unravel the effects of digestibility and limitation by micronutrients in controlling benthic fauna production. They focussed on the "total" and "available" (i.e. enzymatically hydrolysable) fractions of nitrogenous compounds (amino acids). This approach was conducted at fixed stations (Bay of Banyuls, Sofi, HFF), along a depth gradient (BBLL), and over the whole Gulf of Lion (Moogli, Grémare et al., 2002). Available amino acid concentrations showed important seasonal changes in relation both with pelagic primary production and sediment resuspension. Organic matter and carbohydrate concentrations were associated to the most refractory fraction, whereas lipid and available amino acid concentrations were associated to the most labile fraction of sedimented POM. Tempo- 
ral changes in total amino acid spectra always remained low (Medernach et al., 2001). When existing those changes were mostly associated to strong hydrodynamic events enhancing sediment resuspension. Temporal changes in available amino acid spectra were even lower. Their spatial changes were negligible as well. This suggests that digestibility is the most important factor when assessing sedimented POM nutritive value.

Rosenberg et al., 2003a, 2003b recently tested the use of sediment profile imagery (SPI) as a surrogate for classical fauna analysis to assess the quality of benthic habitats in the Gulf of Lion. Their sampling design encompassed five different areas located: in the Berre Lagoon, in the Gulf of Fos, off the mouth of the Rhone river, off Saint Cyprien and off Banyuls-sur-Mer. Results support the use of SPI as a basis for the classification of Mediterranean benthic habitats and confirmed the good correlation between labile fraction of sedimented organic matter and both the abundance and the composition of benthic fauna. They also pinpointed the potential importance of trawling in structuring benthic habitats.

\subsubsection{Water-sediment exchanges}

Denis et al. (2001) and Denis and Grenz, this issue assessed water-sediment exchanges of oxygen and nutrients using core incubation technique. Because of the general oligotrophy in the Mediterranean Sea, exchanges remain low for a continental margin. Both the oxygen benthic demand and the release of nutrients tend to increase towards the coast and the mouth of the Rhone river, with a temporal variability linked to the river discharge and to the spring phytoplankton bloom. Dissolved fluxes are positively correlated with sediment organic content. The influence of the Rhone river decreases near the continental shelfbreak because of the forcing by the North-Mediterranean current. In the whole Gulf of Lion, superficial sediments mineralise $342 \mathrm{kt}$ of organic carbon a year, and the subsequent release of nutrients is comparable to the inputs from the Rhone river or from the North-Mediterranean current. This constitutes a nonnegligible fraction of nutrient requirements for primary production, showing the importance of water-sediment exchanges in controlling continental margin biogeochemical cycles.

\subsubsection{Effect of meteorological hazards}

Grémare et al., 2003a, 2003b this issue described the effect of a severe winter storm on the functioning of the coastal ecosystem. This storm induces a significant increase in total suspended matter, of the proportion of refractory POM and the nutrient availability in the water column through resuspension and desorption processes. Bacterial biomass and production are significantly, albeit temporarily, enhanced by the storm. The distribution of plant pigments is modified at the immediate vicinity of the water-sediment interface but the storm had no effect on integrated phytoplanktonic biomass. The storm induces a significant decrease of meiofauna abundance. The duration of the relax- ation periods varied among parameters. It lasted 2 weeks for total suspended matter, surface sediment granulometry and carbohydrate contents.

\subsection{Budgets of matter}

\subsubsection{Budgets of mass, organic carbon and phosphorus}

Durrieu de Madron et al. (2000) built a budget of particulate matter and organic carbon considering the inputs (river supply, atmospheric deposition and primary production) and outputs (sediment burial, off-shelf advective export, degradation of particulate organic carbon in the water column and at the sediment-water interface). They estimated that mass and particulate organic carbon budgets are balanced within uncertainties and suggest that less than $10 \%$ of the total inputs are exported toward the adjacent deep basin. Lapouyade and Durrieu de Madron (2001) further showed the advective fluxes of matter at the limit of the gulf yield a larger export in winter than in summer. The winter increase results from an increase of the reservoir of material on the shelf and the intensification of the physical shelf-slope exchanges. Export of the particulate matter by the horizontal currents is two orders of magnitude larger than vertical particulate fluxes measured simultaneously with particles traps on the continental slope.

For Van den Broeck and Moutin (2002) the total phosphorus pool in the upper $10 \mathrm{~cm}$-layer of the sediments in the gulf was estimated at $562 \mathrm{kt}$ with about $80 \%$ trapped into the shelf. Annual phosphorus deposition was estimated as 7.2$12.4 \mathrm{kt}$, which is equivalent to the Rhone river input. As the Rhone is the major river flowing into the Mediterranean Sea, surface sediments of the Gulf of Lion should be taken into account in phosphorus budgets at the scale of the Mediterranean Sea.

\subsubsection{Seasonal budgets of nutrients during the Moogli cruises}

A work conducted in collaboration with the Land-Ocean Interactions in the Coastal Zone (LOICZ) program aims at assessing the current knowledge of carbon, nitrogen and phosphorus fluxes on the Gulf of Lion' continental shelf on three Moogli surveys (Durrieu de Madron et al., 2001, 2003a). It attends to provide a robust quantification of the flow of dissolved and particulate nutrients across the system boundaries so as to quantify the nutrients budgets on the shelf. These budgets consider river discharges, urban sewage supply, fish catches, atmospheric deposition, and fluxes at the water-sediment and shelf-slope interfaces. Results indicate that shelf-slope exchanges by mixing predominate with respect to the major input terms (river discharge and sediment release). Budgets for inorganic nutrients, that show a strong concentration gradient between the shelf and the slope waters, are significantly different from zero and indicate an excess of these elements in the shelf water. For all surveys, these surpluses suggest (i) that the whole shelf system is autotrophic $\left(1.6-4.3 \times 10^{3} \mathrm{~mol} \mathrm{C} \mathrm{s}^{-1}\right)$ and acts as a sink of 
$\mathrm{CO}_{2}$, and (ii) that it is a site of net denitrification $\left(119 \mathrm{~mol} \mathrm{~N} \mathrm{~s}^{-1}\right)$ and acts as a sink of $\mathrm{N}_{2}$. Average shelf-slope fluxes of dissolved and particulate organic elements suggest an export to the open sea.

In the framework of the Continental Margin Task Team (CMTT) of the LOICZ and JGOFS programs, the previous budgeting work was integrated in a review of the input, transport and fate of nutrients on major continental margins of the Mediterranean Sea (Durrieu de Madron et al., 2003b). It provides the general characteristics of the Mediterranean Sea in terms of physiography, oceanic circulation, nutrients inputs and distribution, then describes the flux of nutrients for the major sub-systems (i.e. the Gulf of Lion, the Adriatic Sea and the Aegean Sea). These descriptions define the critical input/output terms and the key shelf-slope exchanges processes. It finally addresses the temporal changes of the input of nutrients to the Mediterranean Sea and the trends of the chemical characteristics of the water masses.

\section{References}

Arnoux-Chiavassa, S., Rey, V., Fraunié, P., 2003. Modelling 3-D Rhone River plume using a higher order advection scheme. Oceanol. Acta (2003, this issue).

Auclair, F., Casitas, S., Marsaleix, P., 2000a. a. Application of an inverse method to coastal modelling. J. Atmos. Ocean. Tech. 17, 1368-1391.

Auclair, F., Marsaleix, P., Estournel, C., 2000b. b. Sigma coordinate pressure gradient errors: evaluation and reduction by an inverse method. J. Atmos. Ocean. Tech. 17, 1348-1367.

Auclair, F., Marsaleix, P., Estournel, C., 2001. Specification of the exchanges through the continental shelf breaks in high resolution coastal models: penetration of the LPC current over the Gulf of Lion (Mediterranean). Oceanol. Acta 24 (6), 529-544.

Auclair, F., Marsaleix, P., De Mey, P., 2003. Space-time structure and dynamics of the forecast error in a coastal circulation model of the Gulf of Lions. Dynamics of Atmospheres and Oceans 36 (4), 309-346.

Béthoux, J.P., Durrieu de Madron, X., Nyffeler, F., Taillez, D., 2002. Deep water in the western Mediterranean: peculiar 1999 and 2000 characteristics, shelf formation hypothesis, variability since 1970 and geochemical inferences. J. Mar. Syst. 33-34, 117-131.

Broche, P., Devenon, J.L., Demaistre, J.C., Forget, P., Naudin, J.J., Cauwet, G., 1998. Experimental study of the Rhône river plume-part I: physics and dynamics. Oceanol. Acta 21, 725-738.

Denis, L., Grenz, C., Alliot, E., Rodier, M., 2001. Temporal variability in dissolved inorganic nitrogen fluxes at the sediment-water interface and related annual budget on a continental shelf (NW Mediterranean. Oceanol. Acta 24, 85-97.

Denis, L., Grenz, C., 2003. Spatial variability in oxygen and nutrient fluxes at the sediment-water interface on the continental shelf in the Gulf of Lion (NW Mediterranean Sea. Oceanol. Acta (2003, this issue).

Diaz, F., 2000. Evolution saisonnière de la production primaire et des processus d'assimilation/régénération de l'azote dans le golfe du Lion. Estimation d'un bilan de carbone. Approches in situ et modélisation. Ph.D., Univ. Aix-Marseille II, Marseille, France. pp. 351 p.

Diaz, F., Raimbault, P., 2000. Nitrogen regeneration and DON release during ${ }^{15} \mathrm{~N}$ experiments during spring in a northwestern Mediterranean coastal zone (Gulf of Lion): implications on the estimations of $\mathrm{f}$ ratio and new production. Mar. Ecol. Progr. Ser. 197, 51-65.

Diaz, F., Raimbault, P., Conan, P., 2000. Carbon and nitrogen utilization by phytoplankton during spring in a Mediterranean coastal zone (Gulf of Lion): evidence of small-scale variability. Cont. Shelf Res. 20, 975-996.
Diaz, F., Raimbault, P., Boudjellal, B., Garcia, N., Moutin, T., 2001. Early phosphorus limitation during spring in the Gulf of Lions. Mar. Ecol. Progr. Ser. 211, 51-62.

Durrieu de Madron, X., Abassi, A., Heussner, S., Monaco, A., Aloisi, J.C., Radakovitch, O., Giresse, P., Buscail, R., Kerhervé, P., 2000. Particulate matter and organic carbon budgets for the Gulf of Lion (NW Mediterranean). Oceanol. Acta 23 (6), 717-730.

Durrieu de Madron, X., Denis, L., Diaz, F., Garcia, N., Guieu, C., Grenz, C., Löye-Pilot, M.D., Ludwig, W., Moutin, T., Raimbault, P., 2001. Coastal systems of France; the western Mediterranean sea. In: Dupra, V., Smith, S.V., Marshall, J.I., Crossland, C.J. (Eds.), Coastal and Estuarine Systems of the Mediterranean and Black Sea Regions: Carbon, Nitrogen and Phosphorus Fluxes. LOICZ Reports and Studies No. 19, LOICZ. Texel, The Netherlands, pp. 67-76.

Durrieu de Madron, X., Denis, L., Diaz, F., Garcia, N., Guieu, C., Grenz, C., Loÿe-Pilot, M.D., Ludwig, W., Moutin, T., Raimbault, P., Ridame, C., 2003a. Nutrients and carbon budgets for the Gulf of Lion during the Moogli cruises. Oceanol. Acta (2003, this issue).

Durrieu de Madron, X., Ludwig, W., Civitarese, G., Gacic, M., Ribera d'Alcalà, M., Raimbault, P., Krasakopoulou, E., 2003b. Shelf-slope nutrients and carbon fluxes in the Mediterranean Sea. In: Atkinson, L., Liu, K.K., Quinones, R., Talaue-McManus, L. (Eds.), Carbon and Nutrient Fluxes in Global Continental Margins. Springer, New York (2003b, in press).

Echevin, V., Crépon, M., Mortier, L., 2003a. Analysis of the mesoscale circulation in the North Western Mediterranean Sea simulated in the framework of the Mediterranean Forecast System Pilot Project. Ann. Geophys. 21 (1), 281-297.

Echevin, V., Mortier, L., Crépon, M., 2003b. Interaction of a coastal current with a gulf: application to the shelf circulation of the Gulf of Lion in the Mediterranean Sea. J. Phys. Oceanogr. (in press).

Estournel, C., Broche, P., Marsaleix, P., Devenon, J.L., Auclair, F., Vehil, R., 2001. The Rhone river plume in unsteady conditions: numerical and experimental results. Estuar. Coast. Shelf Sci. 53, 25-38.

Estournel, C., Durrieu de Madron, X., Marsaleix, P., Auclair, F., Julliand, C., Vehil, R., 2003. Observations and modelisation of the winter coastal oceanic circulation in the Gulf of Lions under wind conditions influenced by the continental orography (FETCH experiment. J. Geophys. Res. 108, C3, 8059.

Flexas, M., Durrieu de Madron, X., Garcia, M.A., Canals, M., Arnau, P., 2002. Flow variability in the Gulf of Lion during the MATER HFF Experiment (March-May 1997). J. Mar. Syst. 33-34, 197-214.

Forget, P., Broche, P., Naudin, J.J., 2001. Reflectance sensitivity to solid suspended sediment stratification in coastal water and inversion. Remote Sens. Environ. 77, 92-103.

Forget, P., Ouillon, S., Lahet, F., Broche, P., 1999. Inversion of reflectance spectra of non-chlorphyllous turbid coastal waters. Remote Sens. Environ. 68, 264-272.

Gaudy, R., Youssara, F., Diaz, F., Raimbault, P., 2003. Biomass, metabolism and nutrition of zooplankton in the Gulf of Lions (NW Mediterranean. Oceanol. Acta (2003, this issue).

Grémare, A., Amouroux, J.M., Cauwet, G., Charles, F., Courties, C., deBovée, F., Dinet, A., Devenon, J.L., Durrieu de Madron, X., Ferré, B., Fraunié, P., Joux, F., Lantoine, F., Lebaron, P., Naudin, J.J., Palanques, A., Pujo-Pay, M., Zudaire, L., 2003a. The effects of a strong winter storm on physical and biological variables at a shelf site in the Mediterranean. Oceanol. Acta (2003a, this issue).

Grémare, A., Medernach, L., deBovée, F., Amouroux, J.M., Charles, F., Dinet, A., Vétion, G., Albert, P., Colomines, J.C., 2003b. Relationship between sedimentary organic matter and benthic fauna within the Gulf of Lion: synthesis on the identification of new biochemical descriptors of sedimentary organic nutritional value. Oceanol. Acta (2003b, this issue).

Grémare, A., Medernach, L., deBovée, F., Amouroux, J.M., Vétion, G., Albert, P., 2002. Relationships between sedimentary organics and benthic meiofauna on the continental shelf and the upper slope of the Gulf of Lion (NW Mediterranean). Mar. Ecol. Progr. Ser. 234, 85-94. 
Lapouyade, A., Durrieu de Madron, X., 2001. Seasonal variability of the advective transport of suspended particulate matter and organic carbon in the Gulf of Lion (NW Mediterranean. Oceanol. Acta 24, 295-312.

Leblanc, K., Quéguiner, B., Garcia, N., Rimmelin, P., Raimbault, P., 2003. Silicon cycle in the Northwestern Mediterranean Sea: seasonal study of a coastal oligotrophic site. Oceanol. Acta (2003, this issue).

Moutin, T., Raimbault, P., Golterman, H.L., Coste, B., 1998. The input of nutrients by the Rhône river into the Mediterranean Sea: recent observations and comparison with earlier data. In: Amiard, J.C., Le Rouzic, B., Berthet, B., Bertru, G. (Eds.), Oceans, Rivers and Lakes: Energy and Substance Transfers at Interfaces. Hydrobiologia, 373/374, pp. 237-246.

Medernach, L., Grémare, A., Amouroux, J.M., Colomines, J.C., Vétion, G., 2001. Temporal changes in the amino acid contents of particulate organic matter sedimenting in the Bay of Banyuls-sur-Mer (northwestern Mediterranean. Mar. Ecol. Progr. Ser. 214, 55-65.

Naudin, J.J., Cauwet, G., Fajon, C., Oriol, L., Terzic, S., Devenon, J.L., Broche, P., 2001. Effect of mixing on microbial communities in the Rhone river Plume. J. Mar. Syst. 28, 203-227.

Petrenko, A., 2003. Circulation features in the Gulf of Lions, NW Mediterranean Sea; summer versus winter conditions. Oceanol. Acta. (this issue).

Rosenberg, R., Grémare, A., Amouroux, J.M., Nilsson, H.C., 2003a. Benthic habitats in the northwest Mediterranean characterized by sedimentary organics, benthic macrofauna and sediment profile images. Estuar. Coast. Shelf Sci. (in press).
Rosenberg, R., Nilson, H.C., Grémare, A., Amouroux, J.M., 2003b. Effects of demersal trawling on marine sediments analysed by sediment profile imagery. J. Exp. Mar. Biol. Ecol. 285-286, 465-477.

Thill, A., Moustier, S., Garnier, J.M., Estournel, C., Naudin, J.J., Bottero, J.Y., 2001. Evolution of particle size and concentration in the Rhone river mixingzone: influence of salt flocculation. Cont. Shelf Res. 21, 2127-2140.

Tusseau-Vuillemin, M.H., Mortier, L., Herbaut, C., 1998. Modeling nitrate fluxes in an open coastal environment (Gulf of Lions): transport versus biogeochemical processes. J. Geophys. Res. 103, 7693-7708.

Van den Broeck, N., Moutin, T., 2002. Phosphate in the sediments of the Gulf of Lion (NW Mediterraean Sea), relationship with input by the river Rhone. Hydrobiologia 472, 85-94.

Van Wambeke, F., Heussner, S., Diaz, F., Raimbault, P., Conan, P., 2002. Small-scale variability in the coupling/uncoupling of bacteria, phytoplankton and organic carbon fluxes along the continental Margin of the Gulf of Lion, Northwestern Mediterranean Sea. J. Mar. Syst. 33-34, 411-429.

Verdier-Bonnet, C., Angot, P., Fraunie, P., Coantic, M., 1999. Threedimensional modelling of coastal circulations with different $k-\epsilon$ closures. J. Mar. Syst. 21, 321-339.

Younes, W., Bensoussan, N., Romano, J.C., Arlhac, D., Lafont, M., 2003. Seasonal and interannual variations (1996-2000) of the coastal waters east of the Rhône river mouth as indicated by the Sorcom series. Oceanol. Acta (2003, this issue). 